\title{
The effect of stocking density and bin feeder space on performance in pigs \\ G.A. Lavers ${ }^{\#}$ and N.S. Ferguson
}

School of Agricultural Sciences \& Agribusiness, University of Natal, P Bag X01, Scottsville 3209

"Email: lavers@agric.unp.ac.za

\section{Introduction}

Pigs housed individually have been shown to have higher feed intakes and consequently better performance than grouped pigs (Nielsen et al., 1996). This experiment was designed to determine the effect of feed bin number on growth and feed intake.

\section{Materials and Methods}

The experiment was a $4 \times 2$ factorial design, the respective factors being four bin treatments and two group sizes ( 7 or 13 pigs/pen; 1.0 or $0.5 \mathrm{~m}^{2} / \mathrm{pig}$ ). Two hundred and forty male Large White $\mathrm{x}$ Landrace pigs were purchased at approximately $20 \mathrm{~kg}$ live weight and grown on a commercial starter until an average pen weight of $25 \mathrm{~kg}$ live weight. The pigs were randomly allocated to each bin treatment. Once an average of $25 \mathrm{~kg}$ live weight was reached, all pigs were fed a commercial grower ration (pelleted) for the duration of the trial. All animals were kept on their respective treatments until an average pen weight of $60 \mathrm{~kg}$ live weight was reached. The group pen facility was an open-sided house. The group pen size was $6.9 \mathrm{~m}^{2}(2.3 \times 3.0 \mathrm{~m})$. Each pen had 2 nipple drinkers and plastic feed bins. All animals had free and continuous access to food and water and were weighed weekly. Feed quantities in the bins were checked twice daily. Feed intakes were determined by calculating the difference in weight of the feeder at the beginning and end of each week. The results were analysed by analysis of variance using a factorial design with bin number and group size as factors. Data was analysed using Minitab (1994).

\section{Results and Discussion}

There were no significant differences between the main effects of feed bins/pen and number of pigs/pen on any production characteristic. Similarly there were no significant interaction between bin and pig numbers per pen Table 1.

Table 1. The effect of number of bins and pigs per pen on food intake (ADFI), average daily gain (ADG) and feed conversion (FCR) in growing pigs.

\begin{tabular}{ccccc}
\hline $\begin{array}{c}\text { Bin } \\
\text { Numbers }\end{array}$ & $\begin{array}{c}\text { Number of } \\
\text { pigs per pen }\end{array}$ & $\begin{array}{c}\text { ADFI } \\
(\mathrm{kg} / \mathrm{d})\end{array}$ & $\begin{array}{c}\text { ADG } \\
(\mathrm{kg} / \mathrm{d})\end{array}$ & FCR \\
\hline 1 & 7 & 1.66 & 0.767 & 2.164 \\
1 & 13 & 1.59 & 0.732 & 2.172 \\
2 & 7 & 1.58 & 0.727 & 2.173 \\
2 & 13 & 1.47 & 0.686 & 2.143 \\
3 & 7 & 1.59 & 0.728 & 2.184 \\
3 & 13 & 1.55 & 0.728 & 2.129 \\
4 & 7 & 1.64 & 0.751 & 2.184 \\
4 & 13 & 1.61 & 0.702 & 2.293 \\
\hline
\end{tabular}

Pigs are considered to eat to satisfy the nutrient requirements for potential protein and lipid growth. However, it is evident that pigs in groups do not consume as much food as those kept singly and thus fail to meet their requirements (Morgan et al., 1996). The lack of a significant differences between the groups would suggest that the larger groups compensate for the reduced space by feeding for longer and feeding at night (Walker, 1991). Individual pigs within large groups learn to adapt to these constraints by adjusting normal patterns of behaviour. Nielsen et al. (1996) found that the reduced feed intake of grouped animals does not appear to be caused by the pig: trough ratio. 
(C) South African Society of Animal Science

Short paper and poster abstracts: $38^{\text {th }}$ Congress of the South African Society of Animal Science

\section{Conclusion}

From this experiment it would appear that feeder space and pig numbers per pen have no significant effect on feed intake and growth. It is also apparent that the pigs still managed to maintain their feed intake and growth despite the less than ideal conditions. This suggests that pigs manage to adapt to their conditions by adjusting their behaviour. It would appear that pigs adjusted their feeding patterns in an attempt to meet their requirements for protein and lipid growth.

\section{References}

Black, J.L. \& Carr, J.R., 1996. Manipulating Pig Production 4. Australian Pig Science Association. p 84.

Chapple, R.P., 1996. Manipulating Pig Production 4. Australian Pig Science Association. p 87.

Minitab, 1994. User Manual for Minitab Statistical Package.

Morgan, C.A., et al., 1996. Manipulating Pig Production 4. Australian Pig Science Association. p101.

Nielsen, B.L. \& Lawrence, A.B., 1996 Manipulating Pig Production 4. Australian Pig Science Association. p 85. 